Article

\title{
Impact of Movement Control Order (MCO) due to Coronavirus Disease (COVID-19) on Food Waste Generation: A Case Study in Klang Valley, Malaysia
}

\author{
Muhammad Heikal Ismail ${ }^{1, *(D)}$, Tinia Idaty Mohd. Ghazi ${ }^{1}$, Muhammad Hazwan Hamzah ${ }^{2}$ (D), \\ Latifah Abd Manaf ${ }^{3}$, Ramli Mohd Tahir ${ }^{4}$, Ahadi Mohd Nasir ${ }^{4}$ and Ammar Ehsan Omar 4 \\ 1 Department of Chemical and Environmental Engineering, Faculty of Engineering, UPM Serdang 43400, \\ Malaysia; tinia@upm.edu.my \\ 2 Department of Biological and Agricultural Engineering, Faculty of Engineering, UPM Serdang 43400, \\ Malaysia; hazwanhamzah@upm.edu.my \\ 3 Department of Environment, Faculty of Forestry and Environment, UPM Serdang 43400, Malaysia; \\ latifahmanaf@upm.edu.my \\ 4 KDEB Waste Management Sdn Bhd, Shah Alam 40000, Malaysia; ramli@kdebwm.com (R.M.T.); \\ ahadi@kdebwm.com (A.M.N.); ammar@kdebwm.com (A.E.O.) \\ * Correspondence: heikal@upm.edu.my; Tel.: +60-3-9769-4676
}

Received: 11 September 2020; Accepted: 12 October 2020; Published: 25 October 2020

\begin{abstract}
The outbreak of a neurological disorder was first discovered as a new coronavirus (2019-nCoV) in Wuhan, China. The infection spread rapidly in China and throughout the world, including Malaysia. Malaysia recorded its initial case on 25 January 2020 with intensifying numbers since March 2020. Due to this uncertain circumstance, Malaysia has introduced the Movement Control Order (MCO) with the main aim of isolating the source of the COVID-19 outbreak, which was effective from 18 March 2020. The restriction has observed fewer vehicles on the road with industrial and commercial activities being suspended. The objective of the study is to quantify the effects of MCO to food waste generation in town and district areas of Klang Valley, Malaysia. Food waste generation data was derived from the Project Delivery Department, KDEB Waste Management on a daily basis before (19 February-17 March 2020) and during the MCO (18 March-14 April 2020) at 12 local authorities in Selangor, Malaysia. The data was obtained with the limitation of assumption that there is no waste compositional analysis to be conducted in 2020. Despite the stay-at-home order, food waste data showed a descriptive reduction of up to $15.1 \%$ during the MCO. Statistical analysis of food waste generation from one-way variance has shown that municipal and district local authorities recorded a significant reduction $(p<0.50)$ during the MCO. The food waste reduction during the MCO will deliver as the evidence-based results to push the need for policies in Malaysia as per the goals outlined in Sustainable Development Goals of global food loss and waste.
\end{abstract}

Keywords: food waste generation; food waste management; coronavirus disease; movement control order; Malaysia

\section{Introduction}

Coronavirus disease, which was named as COVID-19 by World Health Organization (WHO), is spreading rapidly in almost entire regions of Asia and sustainably in most countries in Europe and North America. The COVID-19 cases were found to be even more acute than SARS-CoV. A cumulative 81,109 test cases were recorded globally by 25 February 2020. As of 3 July 2020, the confirmed COVID-19 cases skyrocketed to $11,084,490$, due to the vulnerable spread of the pandemic with 526,397 deaths [1]. 
Limited information about novel and pathogenic coronaviruses due to the lack of definite treatment has become a challenging and truly rigorous situation for all global scientists [1].

The first COVID-19 case in Malaysia was identified on 25 January 2020 with relatively few reported cases and largely confined to imported cases. It was until localized clusters began to significantly emerge from March 2020, breaching the 2000 active cases mark by the end of March, from less than 30 cases earlier that month. Such explosive COVID-19 pandemic in Malaysia has called for pragmatic preventive measures to be implemented, including intensive case diagnosis, precise tracking, and compulsory two-week quarantine. Therefore, the Malaysian government has declared the enforcement of the Movement Control Order (MCO) as the strategy of flattening the pandemic curve [2].

There has been a significant reduction in traffic and industrial emission since most industrial and commercial activities were strictly not allowed during the first phase of MCO. Higher frequency of activity at home due to stay-at-home orders has possibly increased the percentage of household waste being produced through over-purchasing, especially the food waste. The household is the primary source of Municipal Solid Waste (MSW) in Malaysia. According to Khazanah Research Institute (KRI), the household sector generates $44.5 \%$ of the total solid waste collection data, amounting to 6.1 million tonnes a year. MSW consists of 20 different categories including food waste, which made up $50 \%$ of total waste composition [3].

Food waste is defined as food that is qualified for safe consumption but discarded due to spoilage. Lower-income countries have reportedly wasted food during the production phase, while middle and high-income countries wasted food during the last phase of the household [4]. An increasing earning will contribute to higher amount of food waste due to easier affordability to food access. Food waste quantity is increasing by over-buying, which causes products to already expire before consumption. Due to high organic content, food waste creates a variety of adverse effects on the environment. Food waste disposal through landfilling is estimated to increase the emission of greenhouse gasses to $50 \%$ by 2020 [5].

Food waste management can be summarized into three important phases: reduce the waste at sources, redefine the purpose through feeding, and regenerate the value to power generation or compost products.

Local production disruption occurred at sources, because the livestock, particularly poultry, depended heavily on imported animal feed. However, 16 out of 33 most commonly consumed agricultural products have more than $100 \%$ self-sufficiency ratios (SSR) to indicate higher domestic production. Food production must be well coordinated after the pandemic to reduce the effect on unintended food waste generation. Food waste valorization into animal feed that was usually adopted by the rural community could be also integrated to the urban settlers [6].

Food waste sources in Malaysia were derived from residential, commercial, institutional, commercial, and city areas. In this study, food waste generation is determined daily through its correlated total MSW collection in respective local authorities in Malaysia. The researchers are therefore statistically quantifying food waste generation to observe the significance of MCO towards food waste generation for the municipal and district areas in Klang Valley. The study shall provide the evidence-based consensus for further policy development in Malaysia in regard to food waste generation towards sustainable waste management.

\section{Methods}

\subsection{Data Collection}

In Malaysia, solid waste management is managed by Solid Waste Management and Public Cleaning Corporation (SWCorp), under the Ministry of Housing and Local Government, JPSPN, local authority, and private concessionaires. The concessionaires are responsible towards comprehensive monitoring of the MSW in each state. Selangor, which is located in Klang Valley, is taken as the sample of the study by taking parallel development in Malaysia. The Selangor state government has appointed 
KDEB Waste Management as the private concessionaire to do the waste collection and public cleansing starting 1 November 2018. In this study, the data on Domestic Waste Collection throughout Selangor was conducted by the Project Delivery Department, KDEB Waste Management on a daily basis from 19 February 2020 to 14 April 2020 (Table 1) to determine the relative changes of MSW through a waste weighting method.

Table 1. Duration of solid waste data collection in Selangor.

\begin{tabular}{ccc}
\hline Collection Period & Collection Duration & Abbreviation \\
\hline Four weeks before MCO & 19-25 February 2020 & 4WB MCO \\
Three weeks before MCO & 26 February-3 March 2020 & 3WB MCO \\
Two weeks before MCO & 4-10 March 2020 & 2WB MCO \\
One week before MCO & 11-17 March 2020 & 1WB MCO \\
\hline Week 1 of Phase 1 of MCO & 18-24 March 2020 & W1 P1 MCO \\
Week 2 of Phase 1 of MCO & 25-31 March 2020 & W2 P2 MCO \\
Week 1 of Phase 2 of MCO & 1-7 April 2020 & W1 P2 MCO \\
Week 2 of Phase 2 of MCO & 8-14 April 2020 & W2 P2 MCO \\
\hline
\end{tabular}

The solid waste collection in Selangor covers a total of 12 local authorities, which were selected in this study. The local authority is categorized by its criteria and can be easily identified through its name as shown in Table 2. City Council (Majlis Bandaraya) refers to the city, usually the center of administration that has a population no less than 500,000 with the annual income of more than RM100 million. Municipal Council (Majlis Perbandaran) refers to the city usually main town areas that have a population more than 150,000 and annual income of more than RM20 million. District Council (Majlis Daerah) refers to the other areas not mentioned previously with a population less than 150,000 and annual income of less than RM20 million [7].

Table 2. List of local authorities selected in the solid waste collection in Selangor.

\begin{tabular}{ccc}
\hline City Council & Municipal Council & District Council \\
\hline Majlis Bandaraya Petaling Jaya (MBPJ) & Majlis Perbandaran Ampang Jaya (MPAJ) & Majlis Daerah Kuala Langat (MDKL) \\
Majlis Bandaraya Shah Alam (MBSA) & Majlis Perbandaran Kajang (MPKj) & Majlis Daerah Sabak Bernam (MDSB) \\
& Majlis Perbandaran Klang (MPK) & Majlis Daerah Hulu Selangor (MDHS) \\
& Majlis Perbandaran Selayang (MPS) & Majlis Daerah Kuala Selangor (MDKS) \\
& Majlis Perbandaran Sepang (MPSp) & \\
& Majlis Perbandaran Subang Jaya (MPS) & \\
\hline
\end{tabular}

\subsection{Data Proportional}

The average solid waste generation for the first week of Ramadhan in Selangor recorded a decline to 1112.27 tonnes per day, compared to the similar period of 1884.67 tonnes per day the previous year [8]. Waste composition in 2019 showed that food waste made up 51\% of the total solid waste collection. This percentage has been used as the origin of direct proportional in food waste collection for the similar period in 2019 to 2020 . Thus, food waste percentage of $40.9 \%$ was taken as the basis of average solid waste composition during the MCO in 2020 [9].

\subsection{Limitation of Study}

Food waste percentage of $40.9 \%$ has been used as the proportional assumption in this study since thorough waste compositional analysis could not be conducted in 2020 .

\subsection{Statistical Analysis}

The published results are expressed as mean \pm standard deviation (SD) of triplicates. Relative change (\%) was used in descriptive statistics to analyze total food waste generation against the collection 
period in Selangor [10]. One-way ANOVA was performed to determine the effect of MCO on food waste generation in municipal and district areas. ANOVA test employed Tukey's post hoc analysis. Student's $t$-test was used to compare food waste generation against local authorities. All statistical analyses were conducted with SPSS software (v.12, IBM, SPSS, New York, USA) at a significance level of 0.05 . Difference in means is marked with a letter in figures.

\section{Results and Discussion}

\subsection{Effect of MCO to Total Food Waste Generation in Selangor}

Table 3 describes the total food waste collection in Selangor for the period of before and during the MCO. Total food waste generation for the overall collection period is 104,201 tonnes with a standard error of 381.16, standard deviation of 1008.4, and sample variance of 1,016,955.1. Food waste collection for the previous four weeks before the MCO recorded a consistent trend of minimal relative change. One week before the MCO, 13,927.44 tonnes of food waste was recorded across Selangor. A relative reduction change of $7.88 \%$ to total up to $12,830.48$ tonnes of food waste was observed one week after the MCO. A higher reduction of $14.76 \%$ was recorded in $11,871.70$ tonnes of food waste for the second week of MCO. The outbreak has caused temporary shutdown of commercial and industrial activities, which has forced most people to stay at home [11].

Table 3. Food waste collection in Selangor before and during MCO.

\begin{tabular}{|c|c|c|c|c|c|c|c|c|}
\hline Period & $\begin{array}{l}4 \mathrm{WB} \\
\mathrm{MCO}\end{array}$ & $\begin{array}{l}3 W B \\
\text { MCO }\end{array}$ & $\begin{array}{l}2 \mathrm{WB} \\
\mathrm{MCO}\end{array}$ & $\begin{array}{l}1 \mathrm{WB} \\
\mathrm{MCO}\end{array}$ & $\begin{array}{l}\text { W1 P1 } \\
\text { MCO }\end{array}$ & $\begin{array}{l}\text { W2 P1 } \\
\text { MCO }\end{array}$ & $\begin{array}{l}\text { W1 P2 } \\
\text { MCO }\end{array}$ & $\begin{array}{l}\text { W2 P2 } \\
\text { MCO }\end{array}$ \\
\hline $\begin{array}{l}\text { Food waste } \\
\text { (tonnes) }\end{array}$ & $13,938.0$ & $13,757.4$ & $14,040.8$ & $13,927.4$ & $12,830.5$ & $11,871.7$ & $11,820.7$ & $12,015.3$ \\
\hline $\begin{array}{c}\text { Relative change } \\
(\%)\end{array}$ & $\begin{array}{l}\text { Reference } \\
\text { value }\end{array}$ & -1.3 & 0.75 & -0.08 & -7.95 & -16.10 & -17.83 & -16.27 \\
\hline
\end{tabular}

Based on the previous study on eating behavior among Malaysian urbanites, factors such as working away from home, working mothers, and food varieties have encouraged the practice of eating-out recently [12]. Social transformation through rapid urbanization with many accessible food premises has supported the change of eating pattern among the urbanites. Temporary closure of most businesses during the MCO was observed by the decline of Malaysia's Industrial Production Index (IPI) at $-4.9 \%$ year-on-year (YOY) in March 2020, the steepest since September 2009 [13]. Thus, the shutdown of these non-essential workplaces has directly affected the food waste generation during the MCO.

The reduction in food waste collection is consistently observed at a higher percentage of $15.13 \%$ due to the extension of the MCO, to a total of 11,820.71 tonnes. There is a further decline as observed in the third week of the MCO due to the stricter rules that were enforced. Extended MCO has further slowed down the economic activities, which slumped 32\% YOY in April, as the sharpest decline on record [14]. In fact, stricter MCO rules have changed spending habits as people started saving money and have instead been purchasing primarily essential goods like groceries, household supplies, and health supplements against uncertainty over job and income security [15].

The traffic in the majority of physical shops decreased significantly, and during the MCO, non-important enterprises were ordered to discontinue. Malaysians have therefore spent more time online and are now ready to buy items online. Behavioral changes, such as working from home or looking at new hobbies during the stay-at-home period, also provide new opportunities to deliver online food. Revenue in online food delivery segment is projected to increase by $+45.9 \%$ yoy to reach RM875m in 2020. The segment has recorded an increment of users at $+36.3 \%$ yoy with a total of 6.9million due to MCO with projected market volume of Restaurant-to-Consumer Delivery with RM622m [16]. 
The fourth week of the MCO observed an increase of $1.4 \%$ of food waste levels to $12,015.29$ tonnes. This may be due to the official government announcement to open certain business sectors and commercial activities [17]. Despite this, the status has still recorded a total reduction of $13.73 \%$ from food waste collection before the MCO. This was attributed to the continuous non-operating order for open space market and massive feast that usually escalates food waste generation [8]. In general, people have started realizing the value of food since important food commodities including rice, beef, and mutton have self-sufficiency ratio (SSR) of less than 100\% [18].

\subsection{Effect of MCO to Weekly Food Waste Generation in Selangor}

Figure 1 illustrates food waste collection for 4 weeks before the MCO and the first 4 weeks of MCO. From the figure, it was observed (and indicated with similar letter a) that there were no statistically significant differences $(p<0.05)$ in food waste collection in Selangor against the weekly collection period. Regardless of the consistent trend for the previous four weeks before the MCO, Selangor recorded 2083.86, 1999.37, 1939.96, 1908.69, 1329.21, 2370.07, and 2296.27 tonnes of food waste one week before the MCO. The first week of MCO recorded a slight daily reduction of food waste by following the previous weekly trend. The MCO did not cause panic buying, which usually led to food waste generation due to over-purchasing, since the government has assured that the food supply was enough through the food security fund of RM1b $[19,20]$.

The second week of MCO recorded consistent reduction of 1827.89, 1703.60, 1708.11, 1598.47, 947.80, 2049.27, and 2036.55 tonnes of food waste collection. Such steady reduction was recorded because most people started to realize the value of food toward a more challenging phase of restructuring life after COVID-19 recovery [21]. This is supported by the recent study that found that $70.6 \%$ of citizens are aware about the Value Food No Waste awareness campaign conducted by SW Corp [22]. The study also found that $96.9 \%$ prepared their own meals and $64.4 \%$ purchased them online during the MCO, which has helped minimizing the waste because it was consumed sparingly [23].

The first week of the second phase of MCO reported 1708.93, 1650.49, 1695.55, 1585.81, 935.59, 2099.25 , and 2145.09 tonnes of food waste. The values were found to be slightly reduced because the people had started to familiarize with the new norm. How a person reacts to the outbreak is influenced immensely by individual background, differences from others, and the community. A feeling of stress, fear, and anxiety can be overwhelming and cause strong individual emotions throughout the MCO $[24,25]$. Most of the people reacted to the initial phases of MCO positively as the platform to try out new recipes [26].

There was even a Facebook group instantly joined by 1.922 million users to discuss on failed food recipes, with the name Masak Apa Tak Jadi Hari Ini Official, that was humorously advised by the Prime Minister on his aspiring speech [27]. This has become an intimidating trend that the members of the Facebook group turned the food into intentionally lousy ones just to gain more likes and engagement [28]. As the food was not prepared properly according to the number of appropriate households, which was facing the increasing time spent and number of people staying at home during the MCO, if not addressed properly, this will contribute to the avoidable amount of food waste [10].

In evidence to this situation, the second week of the second phase of MCO has documented an increase of 1795.97, 1704.67, 1724.25, 1645.21, 953.64, 2071.65, and 2118.67 of consistent food waste status pattern. Based on the survey conducted by vase.ai on Malaysian consumer patterns during the COVID-19 outbreak, the percentage of stocked up food was increasing, compared from Phase 1. Fresh food, particularly, has observed the higher percentage of $75 \%$ from 1100 total respondents rather than only $60 \%$ during Phase 1 [29]. This increment was also due to the exemption for several businesses to operate with employees returning to work to contribute slightly to food waste generation at the workplace. 


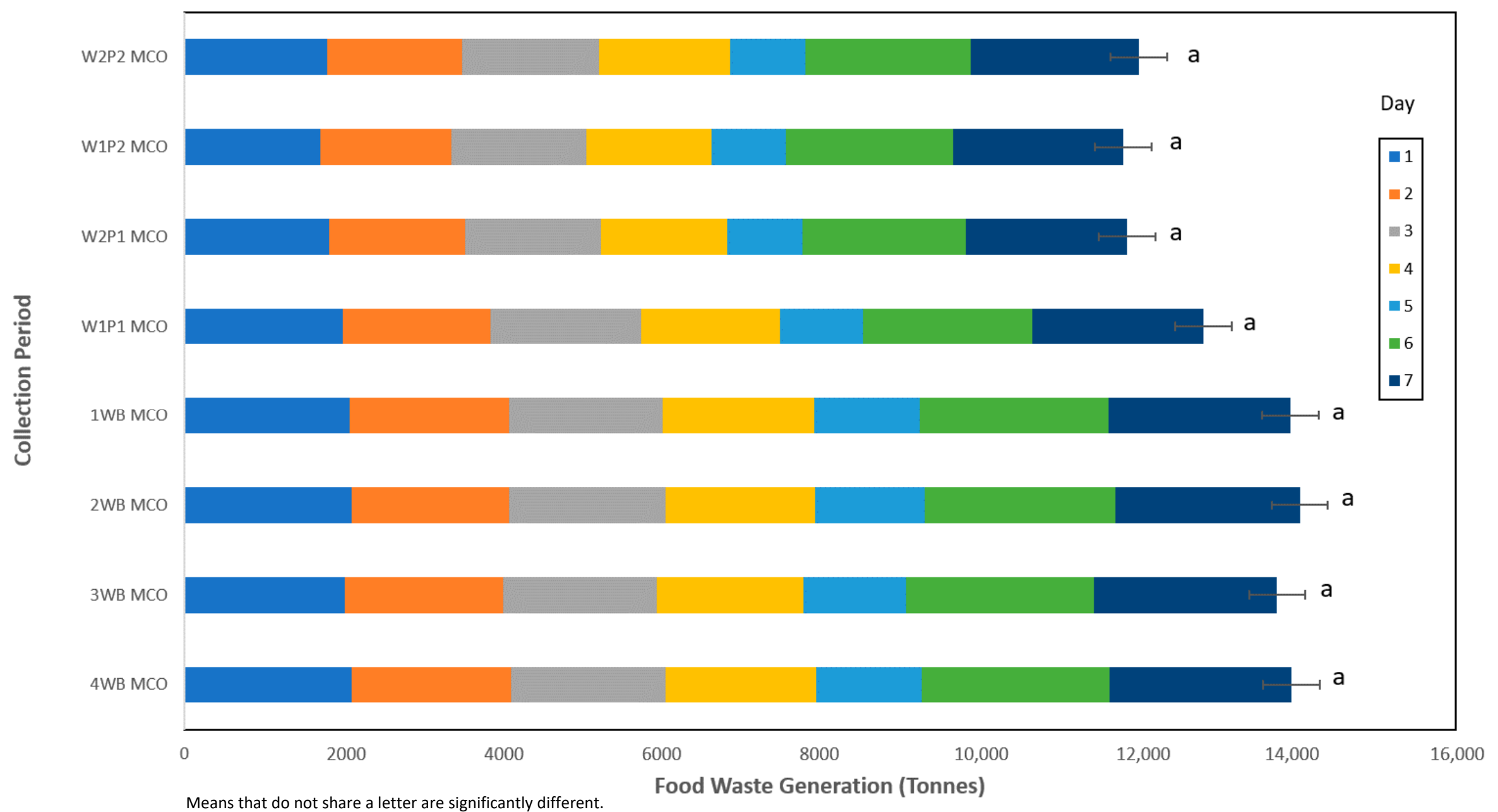

Figure 1. Weekly Food Waste Collection in Selangor (19 February 2020-14 April 2020). 


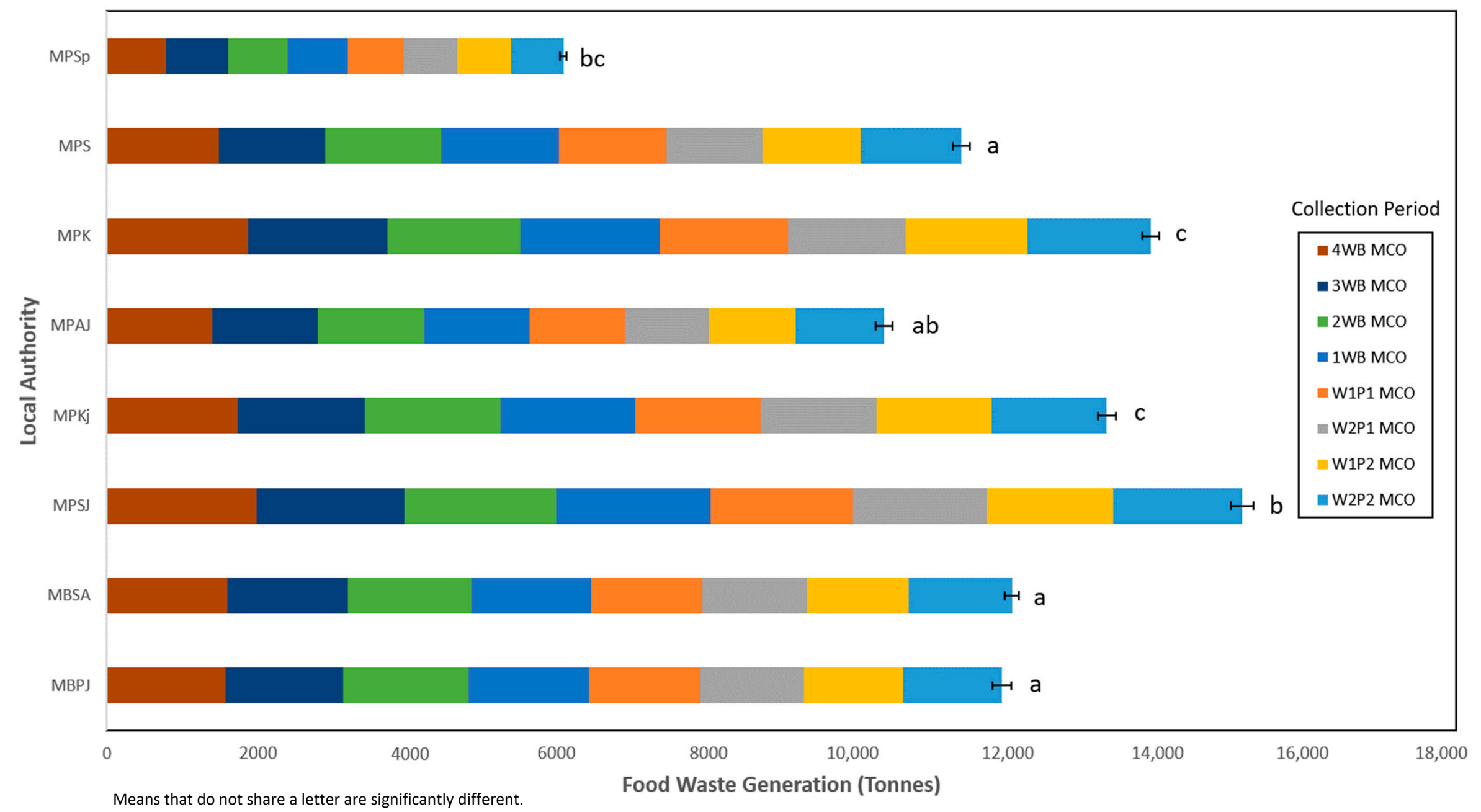

Figure 2. Weekly food waste collection comparison before and during the MCO between municipal areas in Selangor. 


\subsection{The Influence of MCO to Food Waste Generation in Municipal Areas of Selangor}

The effect of MCO on food waste generation according to eight municipal areas in Selangor is shown in Figure 2. Tukey's post-hoc test, as observed with the different letters in the figure, has shown that there is a statistically significant difference $(p<0.05)$ in food waste generation to the local authorities in the municipal areas of Selangor. Food waste generation for the first four weeks before the MCO is still parallel regardless of different local authorities. Indeed, food waste management is critical in influencing the quality of life in urban areas since $70 \%$ of the global population is anticipated to live in cities by 2050 [30] Urban food waste characterization must be studied before policymakers can establish sustainable decisions toward this predicament [31]. Thus, the detailed food waste behavior according to the municipal areas in Selangor is discussed further.

\subsubsection{Majlis Bandaraya Petaling Jaya (MBPJ)}

Now known as the leading growth center in Selangor, Petaling Jaya has recorded a consistently high amount of food waste before the MCO with 3959.17 tonnes for its total population of 520,698 people [32]. There is a consistently gradual drop of food waste generation since the implementation of MCO until week 2 of the second phase, with 1321.36 tonnes. Petaling Jaya is an area of high density with a mixture of office and residential areas. A high number of property holdings of 217,930 that was shut down due to MCO would explain the decline recorded [33]. In fact, a relatively moderate amount of food waste must be attributed to its commitment towards becoming a green city.

Petaling Jaya registered the highest mean household income of the 140 administrative districts with RM10,792 [34]. The ranks of the six highest income groups remained unchanged for several years. Surprisingly, food waste generated by MBPJ was not equally high compared to a higher affordability of purchasing food. Denouncing its green pledge, MBPJ provides Petaling Jaya Homeowners Low Carbon and Green Initiative, which has in total waived assessment worth RM414,380.48 for homeowners practicing green living [35]. The fiscally sustainable green approach by MBPJ has been directly observed by a moderate amount of food waste for such a developed city [36].

\subsubsection{Majlis Bandaraya Shah Alam (MBSA)}

Parallel to its city council counterpart, Shah Alam has a similar food waste data trend to Petaling Jaya, with 1595.60 tonnes before the MCO. This is almost parallel to the total population of 481,654 [32]. MBSA's initiative is to achieve low carbon and green city education in the public sector, especially hawkers and traders [37]. Despite a monthly salary of RM6800 that is sufficient for an average person in Shah Alam to purchase more food, steady food waste reduction on certain points (i.e., 30th of March) during the MCO has reflected the effectiveness of its various initiatives towards the green city concept [38].

\subsubsection{Majlis Perbandaran Ampang Jaya (MPAJ)}

Ampang Jaya has one of the highest drops in food waste quantity, particularly on the 15th and 22nd of March, which are both Sundays. As no residential waste is collected on this day, it can be deduced that the amount of waste generated by office/work-goers decreased. Waste levels have been relatively the same during the second week of the MCO and a slight increase was observed during the fourth week. The previous study on the consumption of $0.38 \mathrm{~kg} / \mathrm{cap} /$ day of rice, eggs, and sugar among the urban community of MPAJ has solely produced $4.5 \mathrm{~kg} / \mathrm{cap} /$ day of food waste [31]. This has indicated that food waste in MPAJ is primarily generated through the residential area with a population of 800,000 [39].

\subsubsection{Majlis Perbandaran Kajang (MPKj)}

Kajang is among the highest food waste producers in Selangor before the MCO, attributed to factories and residential activities, with 1800.82 tonnes. Increased COVID-19 cases in Hulu Langat, 
Kajang, with 357 did not affect food waste generation despite the people having been subjected under restricted MCO with difficult access to food [40] Apparently, high food waste generation was supported by the previous study, in that $50.1 \%$ of the respondents in MPKj were unable to identify the concept of institutional waste. Most of the respondents $(<40 \%)$ have less knowledge on waste facilities associated with an integrated waste management system [41]. However, a consistent drop in food waste generation has remained throughout the MCO due to non-operating industrial activities.

\subsubsection{Majlis Perbandaran Klang (MPK)}

Despite not being the main administrative area, MPK has produced the second highest food waste in Selangor before the MCO, with a significant pattern in waste collection throughout the MCO. This was due to the variety of highly industrialized activities being held here where demand exceeds supply [42]. This is in particular to major industrial parks in Klang, including Pulau Indah Industrial Park, Bandar Bukit Raja Industrial Park, Taman Perindustrian Bandar Sultan Suleiman, etc. The supply of industrial land and ready-built factories grew $11.7 \%$ as one of the largest contributors to Selangor's gross national product from 1Q2013 to 4Q2018 [43].

Moreover, Klang remains a major logistics hub by having Port Klang as the center of international trade and shipment. This has promoted economic events and enhances the quality of living by creating ideal conditions for more infrastructure progress towards a green city goal. Securing the International Apple Award and World Green Award has affirmed its commitment for good practices towards green city initiative. The Ecogen Recycle Bank app is the council's pilot project for Bandar Bukit Rajah residents to participate in a recycling cause. The app will help to tabulate the weight of the recyclable items disposed by the individual households according to the different categories [44].

Unfortunately, the latest pledge was unable to translate any success, as per the observed high amount of food waste generation during the MCO. It was believed to be promoted by the relatively high mean monthly household income of RM8606.00 for an average person in Klang, which encourages over-purchasing [34]. The involvement and support from the developer and 21 precincts from the township were commendable and the residents' association used the money from the sale of recycled items for the residents. Perhaps food waste generation can be significantly reduced by the time the people throughout Klang eventually benefit from the app.

\subsubsection{Majlis Perbandaran Selayang (MPS)}

After the second week of the MCO, Selayang food waste levels remained consistently low, with its lowest percentage drop of $1.41 \%$ observed in the fourth week of the MCO. Despite being strategically located next to Kuala Lumpur, MPS does not record high amount of food waste collection since it is solely contributed by a total population of 410,315 with minimal commercial activities [45]. It was found that post-harvest handling and processing in food supply chain cause relatively high food losses in Southeast Asia region, compared to the household consumption levels with per capita food wasted by consumers in Southeast Asia as only 6-11 kg/year, which was reflected by the data [46].

\subsubsection{Majlis Perbandaran Subang Jaya (MPSJ)}

MPSJ recorded a statistically significant difference $(p<0.05)$ in food waste generation compared to the other local municipalities in Selangor. The overall trend of food waste collection in Selangor during the MCO was primarily made up by these significant municipal authorities. MPSJ demonstrated the highest food waste amount during each week, regardless of the implementation of MCO. This must be hugely contributed by a total population in MPSJ of 708,296 [47]. Food waste generation in MPSJ declined from 2057.06 tonnes to a thinning plunge of 1900.05 before the subsequent reduction from 1787.73 and 1682.32 tonnes during the MCO. This is due to the reduction of commercial waste due to a slight increase of its market at $0.5 \%$ YOY for Subang Jaya [48].

Strict regulations imposed by national health authorities subjected people to stay at home and carefully plan their meals, which led to a change in household food waste behavior $[49,50]$. The amount 
has somehow increased to 1727.33 tonnes during the second phase of MCO. This is attributed to more leeway given for commercial activities being opened by the government since MPSJ is heavily industrialized [17]. Higher average income for MPSJ households with RM6230 usually led to higher tendency of overbuying [51,52]. The influence of households' shopping routines through planned shopping activities can help mitigate the avoidable amounts of food waste [53].

\subsubsection{Majlis Perbandaran Sepang (MPSp)}

As a municipal council, it is not necessary for MPS to produce high amount of food waste generation. With only 797.25 tonnes of food waste before the MCO, the community in MPS has slightly reduced its food waste generation to 744.94 and 718.6. Such low food waste generation is largely due to the initial stage of developing process in MPSp as a spin-off from Kuala Lumpur International Airport 1 and 2 [54]. During the second week of MCO, food waste levels remained consistent at 710.54 and 702.82 tonnes whereby the overall drop was still observed during the week. Minimal residential area with a total population of 212,050 has ascertained the assumption that food waste was generated solely by the internal consumption and production within MPSp [55].

The local industry has attracted skilled workers since 2000, bringing trade and industry growth to the rapid development of MPSp. Relatively higher mean monthly household income of Sepang at RM10,121, dominated by airlines staff with premium salary, somehow did not increase food waste generation in MPSp [56]. However, this has encouraged economic activities, as according to the MPSp Local Plan 2025, 12 areas have been zoned as industrial parks, accumulating 3530 acres. The 196 acres of light to medium industrial development in Sime Darby Property's Serenia City will be continued until 2025 [43]. Indeed, vast urbanization of MPSp is expected to change the pattern of food waste generation for the next ten years.

\subsection{The Influence of MCO to Food Waste Generation in District Areas of Selangor}

The weekly food waste generation tonnage comparison before and during the $\mathrm{MCO}$ according to the local authorities in the rural area of Selangor can be significantly observed from the different letters in Figure 3. It is an agreement that food waste collection for four weeks before the MCO was consistent. MDKL, MDSB, MDHS, and MDKS recorded low food waste collection 1 week before the MCO, at 382.73, 181.03, 394.80, 245.49 tonnes, respectively. The average low amount of daily food waste in the district area of Selangor can be directly correlated to rural Tunisia with 301.01 tonnes. The respondents have indicated positive food waste behavior and agreed that COVID-19 lockdown has affected the waste levels of $93 \%$ respondents and the grocery purchasing preference of $80 \%$. In fact, the lockdown has improved the performance of food purchasing, which has driven towards a positive change in food waste behavior [57]. 


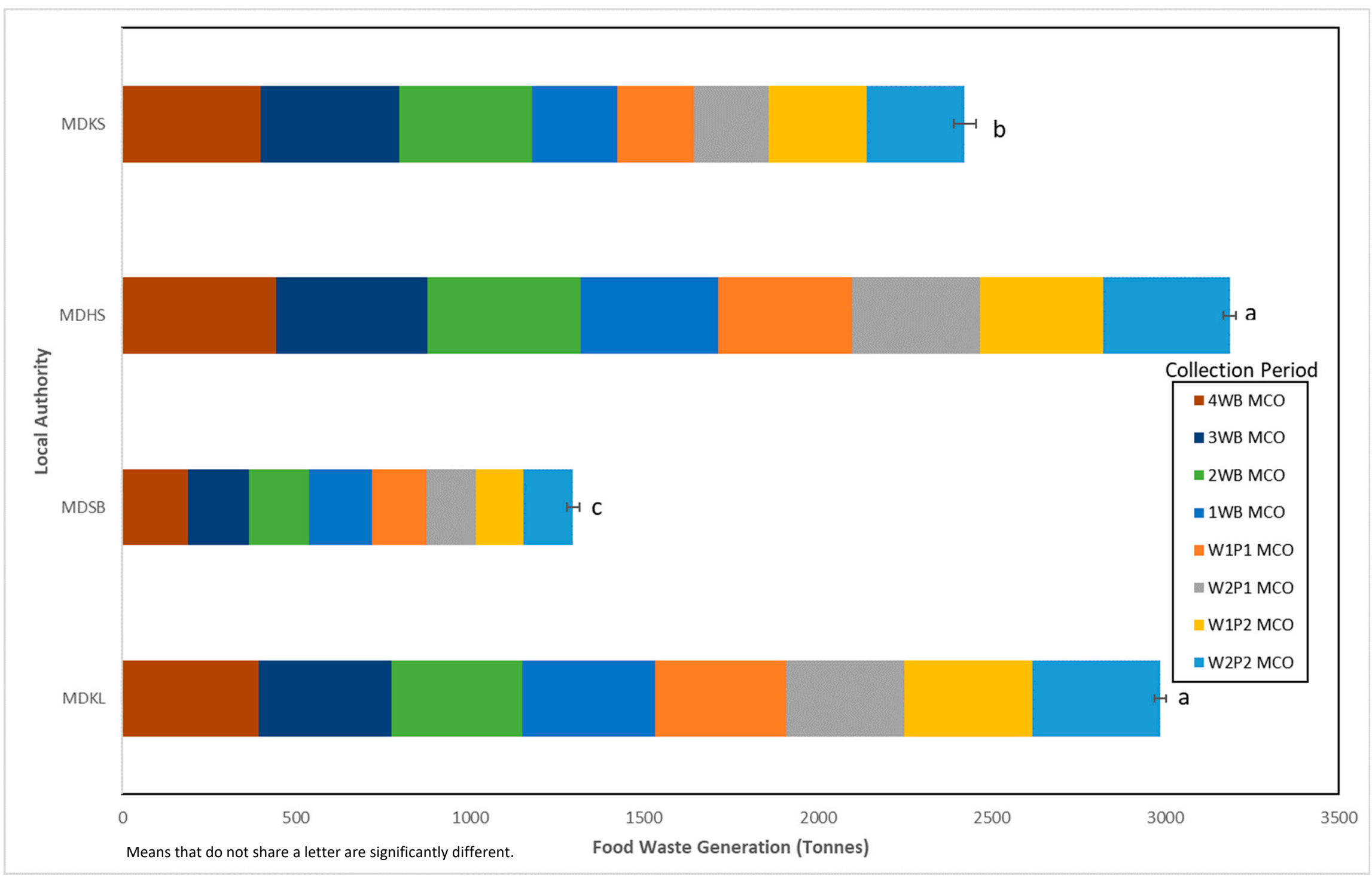

Figure 3. Weekly food waste collection comparison before and during the MCO between district areas of Selangor. 


\subsubsection{Majlis Daerah Kuala Langat (MDKL)}

The food waste amount in MDKL, dominated by rural area, is significantly lower than the urban area, which was previously discussed. MDKL recorded the highest food waste collection at 382.73 tonnes before reducing slightly to 376.38 . The food waste collection fluctuates from 340.26 tonnes to increase to 368.77 tonnes before being reduced back to 367.34 tonnes. The MDKL's initiative of building nine recycling centers was unfortunately a failure due to the apathy and ignorance among the people towards the importance of proper waste treatment [58]. This reflects the low disposal of food waste in rural areas where more houses give their food waste to their neighbors, which demonstrates a brotherhood spirit in their communities [59].

\subsubsection{Majlis Daerah Sabak Bernam (MDSB)}

Tukey's post-hoc test showed that there is a statistically significant difference $(p<0.05)$ in food waste generation in MDSB compared to other local authorities in district areas. MDSB collected a significantly lower total food waste of 181.03 tonnes before the MCO. The amount of food waste reduced consecutively from 155.77 tonnes to 141.49 tonnes. Due to this, it has the highest percentage drop by the second week of the MCO (21.84\%) to 137.17 tonnes as any decrease in waste collected would be a huge chunk in its collected waste portion. Since the land usage for industrial purpose in MDSB is only at $0.05 \%$, such minimal food waste generation might be solely contributed by the low number of total population of 103,709 [60].

The opening of small commercial activities that made up merely $0.14 \%$ of total land usage in MDSB had contributed to a slight increase of food waste to 143.31 tonnes. A percentage of $90.4 \%$ of people in the traditional houses of Sabak Bernam did not use authorized waste management [61]. Since about $47 \%$ of the total area of Sabak Bernam is under agriculture, the traditional agricultural life in Sabak Bernam conducted food waste disposal in nature by feeding to the livestock as grain and plants as fertilizer, which confirmed the low amount of food waste being consistently collected [62]. The main factor affecting agricultural land suitability was rural gross domestic product, which is a crude measure of the disposable income from farming activities. The study found that Sabak Bernam was the most suitable area for paddy, oil palm, and coconut cultivation [63].

\subsubsection{Majlis Daerah Hulu Selangor (MDHS)}

MDHS recorded a total food waste before the MCO that is consistent with MDKL at 394.80 tonnes. Declared as a COVID-19 red zone with 43 positive cases, MDHS was observed with the smallest percentage drop by the second week of the MCO at 387.31 tonnes, compared to all local authorities [40]. It remained at consistent levels of 366.75 and 353.25 tonnes during the third week of the MCO. However, waste levels started to slightly increase during the fourth week, close to before the MCO at 365.48 tonnes. Despite there being no established literature on food waste behavior in Hulu Selangor, it can be deduced to resemble the trend of rural area such as MDKL. As the tonnage drop difference is very small, the data suggests that MCO does not significantly affect food waste generation in MDHS.

\subsubsection{Majlis Daerah Kuala Selangor (MDKS)}

Food waste generation in MDKS recorded a statistically significant difference $(p<0.05)$ compared to the other local authorities in district areas of Selangor. MDKS recorded 245.49 tonnes of food waste before the MCO until it was reduced to 220.34 tonnes and further declined to 214.40 tonnes. The announcement of the Selangor government to designate Kuala Selangor as pioneer districts, where agriculture projects will be created through Agricultural Economic Clusterisation initiative, has ensured food security and sustainability in MDKS [64]. Interestingly, MDKS generated more waste up to 281.74 tonnes and further to 282.38 for the following weeks when people started to get comfortable with the restriction, which were further contributed to by the opening of several business activities. 
3.4.5. Summary of the Effect of MCO on Food Waste Collection in Municipal and District Areas of Selangor

Food waste collection due to the implementation of $\mathrm{MCO}$ in Selangor has recorded significant findings that will deliver as the evidence-based results to push the urge for stricter policies in Malaysia. It was the consensus that the MCO has managed to reduce the food waste generation during the restriction period for both municipal and district areas of Selangor. This is in particular to municipal areas, which relatively recorded very high amounts of food waste before the MCO. On the contrary, for the people in district areas, most of them resorted to the traditional food waste cycle by feeding it to the livestock or as the fertilizer for the plants. Thus, it was clearly indicated by the minimal amount of food waste before and during the MCO, with very slightly lower amount during the MCO.

\subsection{Sustainable Food Waste Management}

The booming world population and changing habits in developing countries could cause food waste to rise by almost a third by 2030. [65]. Regrettably, in developing countries, solid waste management has to address the lack of coverage of the collections and irregular collections; crude open dumping and burns without air and water pollution control; fly and vermin cultivation; and informal waste picker treatment and control [66]. Recently, the management of food waste in the environment has been a major problem because of a lack of separation effort. It causes the technical, financial, institutional, economic, and social factors that limit the development of an effective food waste management system.

The study of the Boston Consulting Group (BCG) found that if current trends persist, annual food waste would rise to 2.1 billion tonnes [67]. Household food waste is particularly important, since it represents the largest fraction of the supply chain compared to other stages and usually helps to raise the fraction of urban waste [68]. Food waste would probably continue to worsen as both individuals and businesses recover from the disrupted food supply chain. Indeed, food prices and availability in Malaysia is subjected to the global food supply chain. As Malaysia imports more than RM50bn worth of food, domestic food consumption could be marginally affected by the chain disruption [69].

Recently, the Ministry of Domestic Trade and Consumer Affairs with the assistance of strategic partners and food donors have developed Centre of Food Collection and Distribution (PPPM) for the Food Bank Malaysia Program (FBMP) located in Bukit Angkat, Kajang. The center has been established as a one-stop center for the donors to contribute food to the identified target groups with the main focus to the community and students from B40. The second PPPM will be opened in Bandar Bahru, Kulim as the center of food collection for the north region. The FBMP has managed to rescue 1984 metric tonnes of food, which has benefited 476,250 households [70]. Thus, the ministry is interested to launch Program Food Bank Siswa (PFBS) with the focus on private universities, polytechnics, and teaching institutes (IPG) [71].

The commitment of Selangor state towards green food waste management is reflected clearly from the 2020 Budget, which saw an allocation of RM6.85 million for solid waste management, RM600,000 to set up recycling centers at all local councils, RM1.5 million for green volunteerism, and RM500,000 to plant 5000 trees statewide [72]. In fact, the sustainability city indicator in Sistem Malaysia Urban Indicator Network (MURNInet), which includes resolving food waste issues, must be consistently evaluated [7,73]. Apart from enhanced awareness on food waste separation, the campaign must be fed well with a food waste recycle initiative by turning it into bio-fertilizer or potential bio-gas through composting or anaerobic digestion [26].

Malaysia's Ministry of Housing and Local Government has confirmed that only $24 \%$ of 38,000 tonnes of generated daily waste is separated and recycled, and $76 \%$ is sent to landfill [74]. There was an $80 \%$ reduction in the quantity of waste received in six landfills in Selangor. KDEB confirmed that the amount of waste collected by residential areas remained almost identical during the MCO and until its implementation [11]. Landfills are usually deprived of environmental reduction measures such as leachate reservoir systems and lining materials. The contamination cannot be mitigated well 
despite adequate landfill reduction measures [75]. Therefore, landfills with informal waste collection require improved safety and management.

\section{Conclusions}

Malaysia has faced similar problems of the ever-growing rates of food waste generation: proper technology, manpower, and scarcity of land and other facilities. Concurrent to this pandemic, the researchers concluded that the MCO restrictions in Malaysia have major effects on the reduction of food waste. The findings will give contribution of knowledge in the quantification and analysis of food waste drivers in Malaysia. Additional considerations should be rendered in the field, for example, industrial activities, weather conditions, biomass burning, and traffic density.

Author Contributions: M.H.I.: conceptualization, visualization, writing-original draft preparation. A.M.N., A.E.O.: methodology, data curation, investigation. R.M.T.: supervision. M.H.H., T.I.M.G. and L.A.M.: writing - reviewing and editing, validation. All authors have read and agreed to the published version of the manuscript.

Funding: This research was supported by Research Management Centre, Universiti Putra Malaysia through the Vote Code of 9001103, Knowledge Transfer Grant Scheme (Ref: UPM/UCTC/900-3/2/KTGS20), and UC Seed Fund for Collaborative Research Grant (Ref: GBG19-1789) for providing technical and financial support for the preparation of the article.

Acknowledgments: A special thanks to the dedicated garbage collectors, particularly in Selangor, as the national essential services during the MCO under KDEB Waste Management and Selangor State Government, Ministry of Housing and Local Government for the promotion on waste segregation and Ministry of Environment and Water for the initiative to promote sustainability in Malaysia. We greatly appreciate the front liners especially the Director-General of Health Malaysia, Tan Sri Dato Seri Dr. Noor Hisham Abdullah, for their hard work during this critical time. Congratulations to fellow Malaysians as we are entering the recovery phase. May the spirit and commitment of Malaysians through \#kitajagakita in facing this pandemic be with you.

Conflicts of Interest: The authors declare that they have no known competing financial interests or personal relationships that could have appeared to influence the work reported in this paper.

\section{References}

1. Bhusare, B. COVID-19: Persistence, Precautions, Diagnosis and Challenges. J. Pure Appl. Microbiol. 2020, 14 (Suppl. S1), 823-829. [CrossRef]

2. Salim, N.; Chan, W.H.; Mansor, S.; Bazin, N.E.N.; Amaran, S.; Faudzi, A.A.M.; Zainal, A.; Huspi, S.H.; Khoo, E.J.H.; Shithil, S.M. COVID-19 epidemic in Malaysia: Impact of lock-down on infection dynamics. medRxiv 2020. [CrossRef]

3. Sundaram, J.K.; Gen, T.Z.; Jarud, R.K. Achieving Food Security for all Malaysians; Khazanah Research Institute: Kuala Lumpur, Malaysia, 2019; pp. 1-78.

4. United States Department of Agriculture. The Impact of Food Waste; United States Department of Agriculture: Washington, DC, USA, 2019.

5. Lim, W.J.; Chin, N.L.; Yusof, A.Y.; Yahya, A.; Tee, T.P. Food waste handling in Malaysia and comparison with other Asian countries. Int. Food Res. J. 2016, 23, S1-S6.

6. Manaf, L.A.; Samah, M.A.A.; Zukki, N.I.M. Municipal solid waste management in Malaysia: Practices and challenges. Waste Manag. 2009, 29, 2902-2906. [CrossRef] [PubMed]

7. Marzukhi, M.A.; Omar, D.; Leh, O.L.H.; Hamir, M.S.; Barghchi, M. Malaysian urban Indicators Network: A sustainable development initiative in Malaysia. Eur. J. Soc. Sci. 2011, 25, 77-84.

8. Penghasilan Sisa Pepejal Menurun Ketika PKP, Ramadan. Available online: https://www.bharian.com. my/berita/nasional/2020/05/686215/penghasilan-sisa-pepejal-menurun-ketika-pkp-ramadan (accessed on 12 July 2020).

9. SWCorp. Analytical Correlation on Solid Waste Data in Malaysia; SWCorp: Cyberjaya, Malaysia, 2020.

10. Jarjusey, F. Consumers' Awareness and Knowledge about Food Waste in Selangor, Malaysia. Int. J. Bus. Econ. Aff. 2017, 2, 91-97.

11. Marked Drop in Waste Sent to Landfills. Available online: https://www.thestar.com.my/metro/metro-news/ 2020/04/11/marked-drop-in-waste-sent-to-landfills (accessed on 10 July 2020). 
12. Ali, N.; Abdullah, M. The food consumption and eating behaviour of Malaysian urbanites. Issues and concerns. Malays. J. Soc. Space 2012, 3, 44-53.

13. MIDF Amanah Investment Bank Berhad, March 2020 Industrial Production Index IPI Fell Into Negative Territory as the MCO Halts. MIDF Research, 12 May 2020.

14. MIDF Amanah Investment Bank Berhad, Record Low Decline in IPI but Recovery Expected Soon. MIDF Research, 20 April 2020.

15. Leong, B. COVID's Impact on Malaysia's e-Commerce Market. Joint ASEAN Network 10, 16 April 2020.

16. Statista. Food Delivery in Malaysia: Projected User Growth; Statista: Hamburg, Germany, 2020.

17. More businesses may be allowed to reopen as Covid-19 curve flattens. The Edge Markets, 29 April 2020.

18. Department of Statistics Malaysia. Self-Sufficiency Ratio (SSR) 2018; Theater; Department of Statistics Malaysia: Putrajaya, Malaysia, 2019; p. 1.

19. Prime Minister's Office of Malaysia. Government Sets up Economic Action Council to Address Economic Woes; Prime Minister's Office of Malaysia: Selangor, Malaysia, 2020.

20. Unilever Malaysia. Will Covid-19 Change Our Relationship with Food Forever; Unilever Malaysia: Kuala Lumpur, Malaysia, 2020.

21. KPMG in Malaysia. Post MCO Reset; KPMG in Malaysia: Kuching Sarawak, Malaysia, 2020.

22. Sinar Harian. SWCorp Lancar Kempen Value Food No Waste. SWM Environment, 23 May 2020.

23. SWCorp. Value Food No Waste Campaign Findings; SWCorp: Cyberjaya, Malaysia, 2020.

24. Ministry of Health Malaysia. Mental health and psychosocial support in Covid-19. Intervention 2020, 13, 235-247.

25. Ozamiz-Etxebarria, N.; Dosil-Santamaria, M.; Picaza-Gorrochategui, M.; Idoiaga-Mondragon, N. Stress, anxiety, and depression levels in the initial stage of the COVID-19 outbreak in a population sample in the northern Spain. Cad. Saude Publica 2020, 36, 1-9.

26. Ismail, M.H. Potensi pengurangan sisa makanan menuju norma baharu. Malaysia Gazette, 13 May 2020.

27. Prime Minister's Office of Malaysia. Perutusan Khas Perdana Menteri (10 April 2020); Prime Minister's Office of Malaysia: Selangor, Malaysia, 2020.

28. Freeman, B.; Kelly, B.; Baur, L.; Chapman, K.; Chapman, S.; Gill, T.; King, L. Digital junk: Food and beverage marketing on facebook. Am. J. Public Health 2014, 104, e56-e64. [CrossRef]

29. Hirschmann, R. Food items that Malaysians have been stocking up during the Movement Control Order (MCO) period during the COVID-19 outbreak in 2020. Vase.ai, 25 May 2020.

30. Liu, C.; Mao, C.; Bunditsakulchai, P.; Sasaki, S.; Hotta, Y. Food waste in Bangkok: Current situation, trends and key challenges. Resour. Conserv. Recycl. 2020, 157, 104779. [CrossRef]

31. Shafie, F.A.; Omar, D.; Karuppannan, S.; Ismail, N. Urban-Scale Material Flow Analysis: Malaysian Cities Case Study. Int. J. Environ. Sustain. 2016, 5. [CrossRef]

32. Worldometer. Malaysia Demographics. worldometers.info, 28 August 2020.

33. Petaling Jaya City Council. Official Portal: Background of Petaling Jaya City Council; Petaling Jaya City Council: Selangor, Malaysia, 2020.

34. Department of Statistics Malaysia. Report of Household Income and Basic Amenities Survey 2016; Department of Statistics Malaysia: Putrajaya, Malaysia, 2017.

35. Priya, S.S. MBPJ offers waivers for green households. The Star, 29 May 2019.

36. Ju, S.R.; Zaki, S.A.; Choi, Y.K. Contextual modernization; New town planning in Petaling Jaya, of Malaysia. J. Asian Archit. Build. Eng. 2011, 10, 93-100. [CrossRef]

37. The Star. Shah Alam on the right track to green city status, says mayor. The Star, 9 June 2017.

38. Salary Explorer. Average Salary in Shah Alam 2020; Salary Explorer: New York, NY, USA, 2020.

39. Hamid, A. Ampang Jaya sets sights on becoming a city. The Star, 1 January 2020.

40. Zulkifli, Z. COVID-19: Hulu Selangor zon merah. Sinar Harian, 10 April 2016; pp. 1-11.

41. Ramlee, W.; Sairi, A.; Azami, Z.; Sopian, K. Basic Perceptions of Integrated Waste Management Concepts in Majlis Perbandaran Kajang Malaysia. Latest Trends Energy Dev. Environ. Biomed. 2007, 2, 87-90.

42. Abas, M.A.; Wee, S.T. Municipal Solid Waste Management in Malaysia: An Insight towards Sustainability. SSRN Electron. J. 2016. [CrossRef]

43. The Edge Markets. Industrial market driving the economy. The Edge Communications Sdn.Bhd, 13 May 2019; pp. 1-19.

44. Perumal, E. International awards spur Klang towards green city goal. The Star, 23 December 2017. 
45. Selayang Municipal Council. Background of Selayang; Official Portal of Selayang Municipal Council: Selangor, Malaysia, 2010.

46. FAO. Global Food Losses and Food Waste_Extent, Causes and Prevention; FAO: Rome, Italy, 2011.

47. World Population Review. Malaysia Population 2020 (Live). Malaysia Population Density Map, 1 July 2020.

48. Chai, Y.H. Klang Valley High-Rise Residential Property Monitor (4Q2019): Property market will remain initiatives-driven. The Edge Markets, 1 April 2020; pp. 1-13.

49. Garcia-Garcia, G.; Woolley, E.; Rahimifard, S.; Colwill, J.; White, R.; Needham, L. A Methodology for Sustainable Management of Food Waste. Waste Biomass Valorization 2017, 8, 2209-2227. [CrossRef]

50. Liu, C.; Hotta, Y.; Santo, A.; Hengesbaugh, M.; Watabe, A.; Totoki, Y.; Allen, D. Magnus Bengtsson. Food waste in Japan: Trends, current practices and key challenges. J. Clean. Prod. 2016, 133, 557-564. [CrossRef]

51. Sulaiman, N.F.A.R.; Ahmad, A. Save The Food for A Better Future: A Discussion on Food Wastage in Malaysia. Int. J. Law Gov. Commun. 2018, 3, 12-21.

52. Salary Explorer. Average Salary in Subang Jaya 2020; Salary Explorer: New York, NY, USA, 2020.

53. Zainal, D.; Hassan, K.A. Factors Influencing Household Food Waste Behaviour in Malaysia. Int. J. Res. Bus. Econ. Manag. 2019, 3, 56-71.

54. Masirin, M.I.H.M.; Ridzuan, M.B.; Mustapha, S.; Don, R.A.M. An Overview of Landfill Management and Technologies: A Malaysian Case Study at Ampar Tenang 1. In Proceedings of the 1st National Seminar on Environment, Development, and Sustainability: Ecological, Economic and Social Aspect, Selangor, Malaysia, 28-29 July 2008; pp. 157-165.

55. Worldometer. Malaysia Population (LIVE). Worldometer, 28 August 2020.

56. Department of Statistics Malaysia. Malaysian Economic Statistics Review; Department of Statistics Malaysia: Putrajaya, Malaysia, 2020.

57. Jribi, S.; Ismail, H.B.; Doggui, D.; Debbabi, H. “COVID-19 virus outbreak lockdown: What impacts on household food wastage? Environ. Dev. Sustain. 2020, 22, 3939-3955. [CrossRef]

58. Jereme, I.A.; Siwar, C.; Begum, R.A.; Alam, M.M. An assessment of waste management operation in Malaysia: Case study on Kuala Langat and Sepang. Int. J. Environ. Waste Manag. 2015, 16, 133-143. [CrossRef]

59. Jereme, I.A.; Siwar, C.; Begum, R.A.; Talib, B.A. Addressing the problems of food waste generation in Malaysia. Int. J. Adv. Appl. Sci. 2016, 3, 68-77. [CrossRef]

60. Portal Rasmi Pejabat Daerah dan Tanah Sabak Bernam. Profil Daerah; Portal Rasmi Pejabat Daerah dan Tanah Sabak Bernam: Selangor, Malaysia, 2015.

61. Shakiba, N.; Shagar, P.; Hod, R. Solid Waste management in Kuala Selangor and Sabak Bernam. IOSR J. Environ. Sci. Toxicol. Food Technol. 2014, 8, 41-46.

62. Ngah, I. Exploring Rural Transformation in Malaysia: A Case of Rice Cultivation Area in Sabak Bernam. In Proceedings of the Ninth International Malaysia Studies Conference (MSC9), Kuala Terengganu, Malaysia, 18-20 August 2014.

63. Olaniyi, A.O.; Ajiboye, A.J.; Abdullah, A.M.; Ramli, M.F.; Sood, A.M. Agricultural land use suitability assessment in Malaysia. Bulg. J. Agric. Sci. 2015, 21, 560-572.

64. Chan, D. More lands for agricultural in Selangor. New Straits Times, 7 September 2019; pp. 2-4.

65. Elks, S. By 2030 We Could Throw Away More Than 2 Billion Tonnes of Food; World Economic Forum: Colony, Switzerland, 2018.

66. Jereme, I.A.; Siwar, C.; Alam, M.M. Waste Recycling in Malaysia: Transition from Developing to Developed Country Waste recycling in Malaysia: Transition from developing to developed country. Indian J. Educ. Inf. Manag. 2014, 4, 1-14.

67. Hegnsholt, E.; Unnikrishnan, S.; Pollmann-Larsen, M.; Askelsdottir, B.; Gerard, M. Tackling the 1.6-Billion-Ton Food Loss and Waste Crisis; The Boston Consulting Group, Food Nation, State of Green: Boston, MA, USA, 2012.

68. ThinkCity. Covid-19 Crisis: Preserving Lives $\mathcal{E}$ Livelihoods, a Guide for Malaysian Policymakers; ThinkCity: George Town, Malaysia, 2020.

69. Hamid, A.A.; Ahmad, A.; Ibrahim, M.; Rahman, N.N.A. Food Waste Management in Malaysia-Current situation and future management options. J. Ind. Res. Technol. 2012, 2, 36-39.

70. Han, D.H. A recycling method of food waste by drying and fuelizing. J. Eng. Appl. Sci. 2017, 12, 3599-3603.

71. Unit Komunikasi Korporat KPDNHEP. PPPM Kajang Buka Lembaran Baharu; Official Portal of Ministry of Domestic Trade and Consumer Affairs: Putrajaya, Malaysia, 2020.

72. Arumugam, T. 'Selangor, a role model for green initiatives'. New Straits Times, 2 November 2019; pp. 12-15. 
73. Amirudin, N.; Gim, T.-H.T. Impact of perceived food accessibility on household food waste behaviors: A case of the Klang Valley, Malaysia. Resour. Conserv. Recycl. 2019, 151, 104335. [CrossRef]

74. Bernama. Pahang sees 10-30pct drop in garbage collection during MCO. News Straits Times, 2 May 2020.

75. Ismail, S.N.S.; Manaf, L.A. The challenge of future landfill: A case study of Malaysia. J. Toxicol. Environ. Health Sci. 2013, 5, 86-96. [CrossRef]

Publisher's Note: MDPI stays neutral with regard to jurisdictional claims in published maps and institutional affiliations.

(C) 2020 by the authors. Licensee MDPI, Basel, Switzerland. This article is an open access article distributed under the terms and conditions of the Creative Commons Attribution (CC BY) license (http://creativecommons.org/licenses/by/4.0/). 